\title{
Stunting and the Associated Factors among Under- five Children in Shire Endaslassie Town, Tigray, North West Ethiopia
}

Dessalegn Geleta ( $\square$ geletadessalegn@yahoo.com )

Ethiopian Public Health Institute https://orcid.org/0000-0002-8725-7049

Neamin Tesfaye

Ethiopian Public Health Institute

Merkeb Zara

Axum University

\section{Research}

Keywords: Shire Endaslassie town, stunting, malnutrition

Posted Date: May 5th, 2021

DOI: https://doi.org/10.21203/rs.3.rs-470895/v1

License: (c) (i) This work is licensed under a Creative Commons Attribution 4.0 International License.

Read Full License 


\section{Abstract}

Background: Globally, 158 million under five children suffer from childhood stunting. On the continent, 87 million stunted were in Asia, 59 million were in Africa and 6 million were in Latin America and Caribbean. In Ethiopian the number of stunting children declines from 6.13 million in 2012 to 5.85 million in 2015 with the prevalence of $38 \%$ as per 2016 EDHS. Objective: To determine the prevalence and associated factors of stunting among 6-59 months of age in Shire Endaslassie Town, northwest Ethiopia.

Methods: A community-based cross-sectional study was conducted in Shire Endaslassie, northwestern Ethiopia, from April 7 to 20, 2017. Multistage sampling technique was used to select 356 study subjects. Child and family status were assessed using the structured questionnaire and anthropometric measurement was conducted to measure nutritional status of the children. Data were cleaned by EPI-Info version 3.5.1, and height for age was converted to Z-score with ENA-SMART software. A multivariable logistic regression analysis was used to investigate factors associated with stunting. An adjusted odd (AOR) with $95 \%$ confidence interval $(\mathrm{Cl})$ is used to show the strength of the association, and variables with $P$ values $<0.05$ are considered statistically significant.

Results: The prevalence of stunting was 35\% (95\% Cl: $30 \%-40 \%)$ among study participants. Unprotected water source $[A O R=3.20,95 \% \mathrm{Cl}:(1.74,5.73)]$, Monthly income 3000 ETB [AOR $=2.59,95 \% \mathrm{Cl}:(1.44$, $4.66)]$, providing breast feeding when only child cry $[A O R=2.22,95 \% \mathrm{Cl}:(1.24,3.99)$ were positively associated with stunting, while, having enough time to prepare meal $[A O R=0.50,95 \% \mathrm{Cl}:(0.30,0.81)]$, usage of family planning $[\mathrm{AOR}=0.26,95 \% \mathrm{Cl}:(0.12,0.56)]$ were found to be preventive factor.

Conclusion The prevalence of stunting was high in the study area. We found that stunting was significantly correlated with monthly income, water source, having enough time to prepare time, time of breastfeeding, and usage of family planning. Therefore, intervention focusing on supporting housewives, family planning, and education on child feeding and nutrition should be implemented.

\section{Background}

Prevalence of under-five stunting and wasting are a sensitive indicator of community health and nutrition. Stunting or height for age is one of three anthropometric measurements commonly used as an indicator of child growth [1]. Stunting is defined as height for age Z(HAZ)score below minus two Z-score of world health organization (WHO) growth reference standards. It also reflects linear growth and its deficit indicates long term cumulative effect of individual health condition [2]. Child stunting can happen in the first 1000 days after conception and its contributed by socioeconomic status, Dietary intakes, maternal nutrition status, childbirth size at birth, poor breastfeeding practices (delayed initiation, nonexclusive breastfeeding and early cessation of breastfeeding) infection, micronutrient deficiency and the environment [13].

Growth failure in the first two years of life is associated with reduced stature in adulthood and ageadjusted height deficit between stunted and non-stunted children was $6.6 \mathrm{~cm}$ for women and $9 \mathrm{~cm}$ in men 
[5]. Stunting has negative consequence both on individual health as well as on economic growth of the country. Adult with short stature has outcomes lower earing and poor productivity in labor market with an estimated $20 \%$ with adult non-stature [9,10]. It is also associated with higher morbidity and mortality [3,4]. Stunting is associated with higher risk of choric illness like elevated blood pressure, renal dysfunction, alerted glucose concentration and increase harmful lipid profile [6-8]. Generally, the impact will be expressed in terms of delayed mental development, poor educational performance, reduced intellectual capacity, and low economic productivity. Generally, it is a strong predictor of human capital and social progress.

Globally, 158 million children of under five age group suffer from childhood stunting, in 2016. Continent wise 87 million stunted were in Asia, 59 million were in Africa and 6 million were in Latin America and Caribbean. Five sub-regions have child stunting rates that exceed 30\%: western Africa (31.4\%), middle Africa (32.5\%), eastern Africa (36.7\%), southern Asia (34.1\%) and Oceania (38.3\%; excluding Australia and New Zealand). Asia and Oceania have experienced slow or minimal progress in reducing child stunting. However, stunting has declined twice in Latin America and the Caribbean, when compared with Africa from 2000 to 2016 [11].

In Ethiopian, stunting declines from 6.13 million in 2012 to 5.85 million in 2015. According to 2016, Ethiopian demographic health survey stunting is reduced to $38 \%$ from $40.4 \%$ in 2014 . Region-wise, it ranges from $15 \%$ in Addis Ababa city administration to that of $46 \%$ in the Amhara region [12].

Ethiopia has endorsed major global and national initiatives to see children free from under nutrition including stunting. The Seqota Declaration to end stunting in children under two by 2030 and the Health Sector Transformation Plan to reduce childhood stunting in under-five years from $40 \%$ to $26 \%$ by the end of the year 2020 are part of the national initiatives [14]. Therefore, the study was conducted with the aim of identifying the prevalence and determinate factor of stunting in Shire Endaslassie town, Tigray, Northern West Ethiopia.

\section{Methods}

\section{Study area and design}

A community-based cross-sectional study was conducted in Shire Endaslassie, North Western Ethiopia, from April 7 to 20, 2017. The town is $1074 \mathrm{~km}$ away from the capital Addis Ababa and located at $14^{\circ} 6^{\prime} \mathrm{N}$ $38^{\circ} 17^{\prime} \mathrm{E}$ with an altitude of 1953 meters above sea level [15].

\section{Sample size and sampling procedures}

The study population included children aged 6-59 months in the 3 randomly selected kebeles (local smallest administrative unit) in Shire Endesillasie Town. Seriously ill Children during the whole data collection season and children with spinal curvature (Kiphosis, scoliosis and kiphoscoliosis) were excluded from the study. Three out of five total kebeles in the town were selected using the lottery 
method. The total sample size $(n=356)$ was distributed to each selected kebele proportionally using probability proportional to size of population. The total number of each kebele was obtained from the local kebele administrative office. The sample interval $(k)$ for each kebeles was calculated for each kebeles, and the first household in each kebeles was identified using a random number from $k$ number of households. Finally a systematic random sampling technique was used to select participants from each household. For households with more than one eligible child, random sampling was used to select one child for the study. Mothers or caregivers were interviewed on socio demography, housing condition, child variables (eating habits and history of illness) with a pre tested structured questionnaires. Interview questions were revised, edited, and those found to be unclear were modified after pretest. Trained and experienced data collectors were used to conduct a face to face interview. Anthropometric measurement was conducted on target children to measure the nutritional status. A horizontal wooden length board and a vertical wooden height were used to measure the length of children 6-23 months of age and height of children aged 24-59 months respectively. Both length and height are measured nearest to the $0.1 \mathrm{~cm}$.

\section{Data Processing and Analysis procedures}

The collected data using the interview was coded, entered and cleaned for its completeness and errors, and analyzed using SPSS version 24 statistical software packages. Quantitative variables were expressed as mean ( \pm Standard Deviation), or median (interquartile range); qualitative variables were expressed as a percentage. The anthropometric measurement of height for age (HAZ) was calculated by ENA SMART software, and children less than - 2 SD were classified as stunted. Children with HFA between -2 and -3 SD were classified as moderately stunted and < -3 SD were classified as severely stunted. The monthly income of the household was categorized based on Ethiopian Birr and the baseline was $3000 \mathrm{ETB}$. The stunted versus non-stunted groups were compared using $\mathrm{Chi}^{2}$. Bivariate and multivariable logistic regression were done. Factors potentially associated with stunting in univariate analysis with a p-value of $<0.25$ were included in a backward logistic regression. The strength of association was presented using the odds ratio and $95 \%$ confidence intervals and variables with P-values of $<0.05$ were considered statistically significant.

\section{Results}

\section{Socio demography characteristics of the respondent}

The total of 337 respondents participated in this study with respondents' rate of $90.7 \%(337 / 356)$. The majority of the respondents $288(85.5 \%)$ orthodox region follower and $301(89.3 \%)$ were married. regarding maternal educational status, $287(85.2 \%)$ were attained primary school and above. nearly one third of the household 101(30\%) earned more than 3000 birrs per month. The detail is displayed in Table 1. 
Table 1

Social demographical of the respondent and level of stunting their children in Shire Endassielase, Northwest Tigray, Ethiopia, 2017

\begin{tabular}{llll}
$\begin{array}{l}\text { Socio demographical } \\
\text { characteristics }\end{array}$ & \multicolumn{3}{l}{ Level of stunting } \\
\cline { 2 - 4 } & $\begin{array}{l}\text { Normal } \\
(\%)\end{array}$ & $\begin{array}{l}\text { Moderate } \\
(\%)\end{array}$ & $\begin{array}{l}\text { Severe } \\
(\%)\end{array}$
\end{tabular}

Religion

Orthodox 192(66.6) 74(25.7\%) 22(7.6) 288(85.5) 4.3,0.64,6

Muslim $22(53.7) \quad 16(39.0) \quad 3(7.3) \quad 41(12.2)$

Protestant $5(62.5) \quad 3(37.5)$

$0(0)$

$8(2.4)$

Marital status

\begin{tabular}{|c|c|c|c|c|c|}
\hline Married & 199(66.1) & $79(26.2)$ & $23(7.6)$ & $301(89.3)$ & \multirow[t]{3}{*}{$9.3,0.15,6$} \\
\hline Divorced & $9(52.9)$ & $7(41.2)$ & $1(5.9)$ & $17(5.0)$ & \\
\hline Windowed & $1(16.7)$ & $4(66.7)$ & $1(16.7)$ & $6(1.8)$ & \\
\hline Separated & $10(76.9)$ & $3(21.3)$ & $0(0)$ & $13(3.9)$ & \\
\hline \multicolumn{5}{|l|}{ Maternal Educational level } & \multirow{6}{*}{$\begin{array}{l}32.7,< \\
0.0001,8\end{array}$} \\
\hline Unable to read and write & $16(76.2)$ & $4(19.0)$ & $1(4.8)$ & $21(6.2)$ & \\
\hline Able to read and write & 11(39.7) & $18(62.1)$ & $0(0)$ & $29(8.6)$ & \\
\hline Elementary (1upto 8) & $59(57.3)$ & $37(35.9)$ & $7(6.8)$ & 103(30.6) & \\
\hline Secondary & $63(69.2)$ & 17(18.3) & $11(12.1)$ & $91(27.0)$ & \\
\hline $12+$ & $70(75.3)$ & 17(18.3) & $6(6.5)$ & $93(27.6)$ & \\
\hline \multicolumn{6}{|l|}{ Ethnicity } \\
\hline Tigraway & $206(66.2)$ & $81(26.1)$ & $24(7.7)$ & $311(92.3)$ & \multirow[t]{3}{*}{$11.8,0.02,4$} \\
\hline Amahra & 13(59.1) & $8(34.4)$ & $1(4.5)$ & $22(6.5)$ & \\
\hline Oromo & $0(0)$ & $4(100)$ & $0(0.0)$ & $4(1.2)$ & \\
\hline
\end{tabular}

Family size

\begin{tabular}{|c|c|c|c|c|}
\hline$<3$ & $74(73.3)$ & $20(19.8)$ & $7(6.9)$ & $101(30.0)$ \\
\hline 3_5 & $128(61.1)$ & $64(30.5)$ & $18(8.6)$ & $210(62.3)$ \\
\hline$>6$ & $19(65.4)$ & $9(34.6)$ & $0(0.0)$ & $26(7.7)$ \\
\hline
\end{tabular}

Monthly income 


\begin{tabular}{|c|c|c|c|c|c|}
\hline \multirow{2}{*}{$\begin{array}{l}\text { Socio demographical } \\
\text { characteristics }\end{array}$} & \multicolumn{3}{|c|}{ Level of stunting } & \multirow[t]{2}{*}{ Total } & \multirow[t]{2}{*}{$X 2, P, d f$} \\
\hline & $\begin{array}{l}\text { Normal } \\
\text { (\%) }\end{array}$ & $\begin{array}{l}\text { Moderate } \\
\text { (\%) }\end{array}$ & $\begin{array}{l}\text { Severe } \\
(\%)\end{array}$ & & \\
\hline$<500$ & 23(71.9) & $7(21.9)$ & $2(6.3)$ & $32(9.5)$ & \multirow{4}{*}{$\begin{array}{l}27.2,< \\
0.0001,6\end{array}$} \\
\hline $500-2000$ & $45(47.4)$ & $44(46.3)$ & $6(6.3)$ & $95(28.2)$ & \\
\hline $2000-3000$ & $72(66.1)$ & $28(25.7)$ & $9(8.3)$ & $109(32.3)$ & \\
\hline$>3000$ & $79(36.1)$ & 14(15.1) & $8(7.9)$ & $101(30.0)$ & \\
\hline
\end{tabular}

The majority of mothers $273(81.1 \%)$ got their first delivery at age of 20 up to 34 -year-old. Only $43(12.7 \%)$ mothers had more than six deliveries. Maternal characteristics like usage of family planning were associated with child stunting with significant level of $p<0.0001$. The detail is depicted in Table 2 . 
Table 2

Maternal characteristics of the study participants and level of stunting of their children in Shire Endaslassie, North West, Tigray, Ethiopia 2017

Maternal characteristics

Age at first marriage

$<20$

$20-34$

Age at first delivery

$<20$

$20-34$

$>34$

Number of pregnancies

$\leq 2$

3_5

$>6$

Have history of abortion

Yes

No

Work outside of home

Yes

No

Have enough time to prepare food

Yes

No

Preparation of meals for under five children

Together with adult

Separately

Usage of family planning

Level of stunting

Normal

(\%)

$93(62.8) \quad 42(28.2)$

126(66.7) $\quad 51(27.0) \quad 12(6.3) \quad 189(56.1)$

Moderate

(\%)

Severe

(\%)

Total

$X^{2}, P, d f$

$35(56.5) \quad 22(35.5) \quad 5(8.1) \quad 62(18.4) \quad 9.4,0.05,4$

184(67.4) 70(25.6) 19(7.0) 273(81.1)

$0(0.0)$

1(50.0)

1(50.0) 2(0.6)

\begin{tabular}{lllll} 
132(68.4) & $43(22.3)$ & $18(9.3)$ & $193(57.3)$ & $13.8,0.08$, \\
\cline { 1 - 3 } $66(65.3)$ & $29(28.7)$ & $6(5.9)$ & $101(30.0)$ &
\end{tabular}

$21(48.8) \quad 21(48.8) \quad 1(2.4) \quad 43(12.7)$

$\begin{array}{lllll}13(72.2) & 5(27.8) & 0(0.0) & 18(5.3) & 2^{1.5,0.47,} \\ & & & & \end{array}$

$\begin{array}{lllll}105(60.3) \quad 54(31.0) & 15(8.6) \quad 174(51.6) & 3.4,0.18, \\ 2\end{array}$

114(69.9) $\quad 39(23.9) \quad 10(6.1) \quad 163(49.4)$ 


\begin{tabular}{|c|c|c|c|c|c|}
\hline Maternal characteristics & Level of st & nting & & Total & $X^{2}, P, d f$ \\
\hline Yes & 168(73.0) & $44(19.1)$ & $18(7.8)$ & $203(68.7)$ & \multirow{2}{*}{$\begin{array}{l}27.3,< \\
0.0001,2\end{array}$} \\
\hline No & $50(46.7)$ & $49(46.6)$ & $6(5.7)$ & 105(31.3) & \\
\hline
\end{tabular}

\section{Housing and environmental condition}

The majority of the households $213(63.2 \%)$ used piped water for drinking. The common waste disposal system among the study population is pit 316(93.8\%) and 313(92.8\%) households have latrine as displayed in Table 3. 
Table 3

Housing and environmental condition of the study participants and their level of stunting in Shire Endaslassie, North West, Tigray, Ethiopia, 2017

\begin{tabular}{|c|c|c|c|c|c|}
\hline \multirow[t]{2}{*}{ Housing condition } & \multicolumn{3}{|c|}{ Level of stunting } & \multirow[t]{2}{*}{ Total } & \multirow[t]{2}{*}{$X^{2}, P, d f$} \\
\hline & Normal (\%) & Moderate (\%) & Severe (\%) & & \\
\hline \multicolumn{6}{|l|}{ Roof } \\
\hline Corrugated & $113(63.1)$ & $60(33.5)$ & $6(3.4)$ & 179(53.1) & \multirow[t]{2}{*}{$13.5,0.001,2$} \\
\hline Thatched & 106(67.1) & $33(20.9)$ & $19(12.0)$ & $158(46.9)$ & \\
\hline \multicolumn{6}{|l|}{ Floor-type } \\
\hline Cement & 148(67.0) & $56(25.3)$ & $17(7.7)$ & $221(65.6)$ & \multirow[t]{3}{*}{$24.1,0.65,4$} \\
\hline Ceramics & $22(57.9)$ & 14(36.8) & $2(5.8)$ & $38(11.3)$ & \\
\hline Muddy & $49(62.8)$ & $23(29.5)$ & $6(7.7)$ & 78(23.1) & \\
\hline \multicolumn{6}{|l|}{ Window } \\
\hline Yes & 199(64.4) & $85(27.5)$ & $25(8.1)$ & $309(91.7)$ & \multirow[t]{2}{*}{$2.4,0.29,2$} \\
\hline No & $20(71.4)$ & $8(28.6)$ & $0(0.0)$ & $28(8.3)$ & \\
\hline \multicolumn{6}{|l|}{ Number of rooms } \\
\hline Only one room & $45(60.0)$ & $24(32.0)$ & $6(8.0)$ & $75(22.3)$ & \multirow[t]{3}{*}{$5.2,0.27,4$} \\
\hline Two room & $88(65.7)$ & $40(29.9)$ & $6(4.5)$ & 134(39.8) & \\
\hline Three and above & $86(67.2)$ & $29(22.7)$ & 13(10.2) & $128(38.0)$ & \\
\hline \multicolumn{6}{|l|}{ Kitchen status } \\
\hline Separated & $128(66.7)$ & $52(27.1)$ & $12(6.3)$ & 192(57.0) & \multirow[t]{2}{*}{$1.02,0.59,2$} \\
\hline Not separated & $91(62.8)$ & $41(28.3)$ & $13(9.0)$ & $145(43.0)$ & \\
\hline \multicolumn{6}{|l|}{ Water source } \\
\hline Protected well & $66(55.9)$ & $40(33.9)$ & $12(10.2)$ & $118(35.0)$ & \multirow[t]{3}{*}{$10.4,0.03,4$} \\
\hline Unprotected well & $2(33.3)$ & $3(50.0)$ & $1(16.7)$ & $6(1.8)$ & \\
\hline Pipe water & $151(70.9)$ & $50(22.5)$ & $12(5.6)$ & $213(63.2)$ & \\
\hline \multicolumn{6}{|l|}{ Latrine availability } \\
\hline Yes & $212(67.2)$ & $76(24.4)$ & $25(7.7)$ & $313(92.8)$ & \multirow[t]{2}{*}{$24.5,<0.0001,2$} \\
\hline No & $7(16.1)$ & 17(73.9) & $0(0)$ & $24(7.2)$ & \\
\hline
\end{tabular}




\begin{tabular}{|c|c|c|c|c|c|}
\hline \multirow[t]{2}{*}{ Housing condition } & \multicolumn{3}{|c|}{ Level of stunting } & \multirow[t]{2}{*}{ Total } & \multirow{2}{*}{$X^{2}, P, d f$} \\
\hline & Normal (\%) & Moderate (\%) & Severe (\%) & & \\
\hline Pit & $213(67.4)$ & $78(24.7)$ & $25(7.9)$ & $316(93.8)$ & \multirow[t]{2}{*}{$21.4,<0.0001,2$} \\
\hline Open & $6(28.6)$ & 15(71.4) & $0(0.0)$ & $21(6.2)$ & \\
\hline
\end{tabular}

The proportion of male children participated in the study were $172(51 \%)$ and $158(46.9 \%)$ were at the age of 24-47 months with a mean age of $3.6 \pm 1.2$ year. Regarding birth order $164(48.7 \%)$ was the first child for their family and $323(95.8 \%)$ were fully vaccinated as depicted in Table 4. 
Table 4

Characteristics of under-five children and their level of stunting in Shire Endaslassie, North West, Tigray, Ethiopia, 2017

\begin{tabular}{|c|c|c|c|c|c|}
\hline \multirow[t]{2}{*}{ Characteristics } & \multicolumn{3}{|c|}{ Level of stunting } & \multirow[t]{2}{*}{ Total } & \multirow[t]{2}{*}{$X^{2}, P, d f$} \\
\hline & $\begin{array}{l}\text { Normal } \\
\text { (\%) }\end{array}$ & $\begin{array}{l}\text { Moderate } \\
\text { (\%) }\end{array}$ & $\begin{array}{l}\text { Severe } \\
\text { (\%) }\end{array}$ & & \\
\hline \multicolumn{6}{|l|}{ Sex } \\
\hline Male & $111(64.5)$ & $49(28.5)$ & $12(7.0)$ & $172(51.0)$ & \multirow[t]{2}{*}{$0.2,0.9,2$} \\
\hline Female & $108(65.5)$ & $44(26.7)$ & $13(7.9)$ & $165(49.0)$ & \\
\hline \multicolumn{6}{|c|}{ Age of child (in months) } \\
\hline$<24$ & $41(56.2)$ & $30(41.1)$ & $2(2.7)$ & $73(21.7)$ & \multirow[t]{3}{*}{$10.4,0.03,4$} \\
\hline $24-47$ & 107(67.7) & $38(24.1)$ & $13(8.2)$ & $158(46.9)$ & \\
\hline $48-59$ & $71(67.0)$ & $25(23.6)$ & $10(9.4)$ & 106(31.4) & \\
\hline \multicolumn{6}{|l|}{ Birth order } \\
\hline First & $120(73.2)$ & $30(18.3)$ & $14(8.5)$ & $164(48.7)$ & \multirow[t]{3}{*}{$17.6,0.001,4$} \\
\hline Second & $48(58.5)$ & $26(31.7)$ & $8(9.8)$ & $82(24.3)$ & \\
\hline Third and above & $51(56.0)$ & $37(40.7)$ & $3(3.3)$ & $91(27.0)$ & \\
\hline \multicolumn{6}{|l|}{ Immunization status } \\
\hline Unvaccinated & $2(100)$ & $0(0)$ & $0(0)$ & $2(0.6)$ & \multirow[t]{3}{*}{$7.3,0.12,4$} \\
\hline Partially vaccinated & $5(41.7)$ & $7(583)$ & $0(0)$ & $12(3.6)$ & \\
\hline Fully vaccinated & $212(65.6)$ & $86(26.6)$ & $25(7.7)$ & $323(95.8)$ & \\
\hline \multicolumn{6}{|c|}{$\begin{array}{l}\text { Have a history of severe } \\
\text { illness }\end{array}$} \\
\hline Yes & $12(60.0)$ & $8(40.0)$ & $0(0.0)$ & $20(5.9)$ & \multirow[t]{2}{*}{$2.8,0.2,2$} \\
\hline No & $207(65.3)$ & $85(26.8)$ & $25(7.9)$ & $317(94.1)$ & \\
\hline \multicolumn{6}{|l|}{$\begin{array}{l}\text { Having a habit of } \\
\text { breastfeeding }\end{array}$} \\
\hline Yes & $216(67.1)$ & $88(27.3)$ & $18(5.6)$ & $322(95.5)$ & \multirow[t]{2}{*}{$1.3,0.52,2$} \\
\hline No & $3(20.0)$ & $5(33.3)$ & $7(46.7)$ & $15(4.5)$ & \\
\hline \multicolumn{6}{|l|}{ Time of breastfeeding } \\
\hline When cry & $125(59.2)$ & $76(36.0)$ & $9(4.7)$ & $211(62.1)$ & \multirow{2}{*}{$\begin{array}{l}24.3,< \\
0.001,2\end{array}$} \\
\hline According to time & $95(74.8)$ & $17(13.4)$ & $15(11.8)$ & $127(37.9)$ & \\
\hline
\end{tabular}




\begin{tabular}{|c|c|c|c|c|c|}
\hline \multirow[t]{2}{*}{ Characteristics } & \multicolumn{3}{|c|}{ Level of stunting } & \multirow[t]{2}{*}{ Total } & \multirow[t]{2}{*}{$X^{2}, P, d f$} \\
\hline & $\begin{array}{l}\text { Normal } \\
(\%)\end{array}$ & $\begin{array}{l}\text { Moderate } \\
\text { (\%) }\end{array}$ & $\begin{array}{l}\text { Severe } \\
(\%)\end{array}$ & & \\
\hline \multicolumn{6}{|l|}{ time of weaning } \\
\hline$<4$ month & $124(59.0)$ & $76(36.2)$ & $10(4.8)$ & $210(62.3)$ & \multirow{3}{*}{$\begin{array}{l}23.4,<0.001 \\
2\end{array}$} \\
\hline 4-6 month & $94(74.6)$ & 17(13.5) & 15(11.9) & $126(37.4)$ & \\
\hline$>6$ month & $1(100.0)$ & $0(0)$ & $0(0)$ & $1(0.3)$ & \\
\hline \multicolumn{6}{|c|}{ Frequency of feeding } \\
\hline$<4$ time & $7(70.0)$ & $2(20.0)$ & $1(10.0)$ & $10(3.0)$ & \multirow[t]{2}{*}{$0.33,0.84,2$} \\
\hline 5 and above & 211(69.9) & $90(27.7)$ & $24(7.4)$ & $325(97.0)$ & \\
\hline
\end{tabular}

\section{Prevalence of stunting}

The prevalence of stunting was $118(35 \%)$ in the study population from which25/118(21.3) were severely stunted. The prevalence of stunting was higher among male 61(18.1\%), whereas, the female participant contributes 13 (3.9\%) to severely stunted. Age group between 24-47 months was affected by stunting when compared with other age group. Prevalence of stunting in different age group is described in the following table.

\section{Table 5}

Prevalence of stunting by sex and age group among under-five in Shire Endassilasie town, Northwest, Tigray, Ethiopia in 2017

\begin{tabular}{|llllll|}
\hline Characteristics & $\begin{array}{l}\text { Normal } \\
(\%)\end{array}$ & $\begin{array}{l}\text { Moderate } \\
(\%)\end{array}$ & $\begin{array}{l}\text { Severe } \\
(\%)\end{array}$ & Total (\%) & $\begin{array}{l}\text { Prevalence of stunting } \\
(\%)\end{array}$ \\
\hline Sex & & & & & \\
\hline Male & $111(33)$ & $49(14.5)$ & $12(3.6)$ & $172(51.0)$ & $\mathbf{6 1 ( 1 8 . 1 )}$ \\
\hline Female & $108(32.0)$ & $44(13.1)$ & $13(3.9)$ & $165(49.0)$ & $\mathbf{5 7}(16.9)$ \\
\hline Total & $219(65)$ & $93(27.6)$ & $25(7.4)$ & $337(100)$ & $118(35.0)$ \\
\hline Age of child (in months) & & & & \\
\hline$<24$ & $41(12.2)$ & $30(8.9)$ & $2(0.6)$ & $73(21.4)$ & $\mathbf{3 2 ( 9 . 5 )}$ \\
\hline $24-47$ & $107(31.8)$ & $38(11.3)$ & $13(3.9)$ & $158(46.9)$ & $\mathbf{5 1}(15.1)$ \\
\hline $48-59$ & $71(21.1)$ & $25(7.4)$ & $10(3.0)$ & $106(31.5)$ & $\mathbf{3 5}(10.4)$ \\
\hline Total & $219(65 \%)$ & $93(27.6)$ & $25(7.4)$ & $337(100)$ & $118(35)$ \\
\hline
\end{tabular}




\section{Factors associated with stunting}

Maternal educational status $(\mathrm{COR}=1.94,95 \% \mathrm{Cl}(1.13-3.32))$, monthly income $(\mathrm{COR}=2.42(1.43-4.22)$, Having enough time to prepare meal, preparation of meals for children (COR $=2.76(1.56-4.88)$, water source $(\mathrm{COR}=2.18,95 \%(1.37-3.49)$, Latrine availability $(\mathrm{COR}=0.20,95 \% \mathrm{Cl}(0.10-0.48)$, Waste disposal (COR:5.20,95\% Cl (1.94-13.7) and other five variables were entered to multivariate binary logistics regression model as depicted in Table 6. 
Table 6

Factors of stunting in under-five in Shire Endassilasie town, north, West, Tigray, Ethiopia in 2017 Characteristics Height for age $\operatorname{COR}(95 \% \mathrm{Cl})$ P-value Stunted (\%) Normal (\%)

Maternal education level

Secondary and below

95(80.5)

149(68.0)

$1.94(1.13-3.32) \quad 0.02$

$12+$

23(19.5)

$70(32.0)$

1

Monthly income

$\leq 3000$ birr

96(81.4)

140(63.9)

$2.42(1.43-4.22)$

0.001

$>3000$ birr

22(18.6)

79(36.1)

1

Have enough time to prepare meals

Yes

86 (73.5)

203(93.5)

$0.19(0.10-0.38)$

$<0.0001$

No

$31(25.5)$

14(6.5)

1

Preparation of meals for

under-five children

Together with adult

Separately

33(28.2)

27(12.4)

$2.76(1.56-4.88)<0.0001$

Water source

Unprotected water source

84(71.8)

190(87.6)

1

Protected water source

56(47.5) 64(29.5)

$2.18(1.37-3.49)$

0.001

Latrine availability

Yes

$62(52.5)$

155(70.8)

1

No

101(32.5)

212(67.7)

$0.20(0.10-0.48)$

$<0.0001$

Waste disposal

Open

$17(14.4)$

7(3.2)

1

Pit

$$
\text { 15(12.7) }
$$

6(2.7)

$5.20(1.94-13.7)$

0.001

$$
\text { 103(87.3) }
$$

213(97.3)

Birth order

Third and above

Second

40(33.9)

51(23.3) $\quad 1$

34(28.8)

48(21.9)

$1.10(0.61-2.02)$

0.74 


\begin{tabular}{|lllll|}
\hline Characteristics & \multicolumn{2}{l}{ Height for age } & COR (95\%Cl) & P-value \\
\cline { 2 - 4 } & Stunted (\%) & Normal (\%) & & \\
\hline First & $44(37.3)$ & $120(54.3)$ & $2.13(1.25-3.67)$ & 0.006 \\
\hline Time of breastfeeding & & & & \\
\hline When cry & $86(72.9)$ & $124(56.6)$ & $2.10(1.26-3.34)$ & 0.004 \\
\hline According to time & $32(27.1)$ & $95(43.4)$ & 1 & \\
\hline Usage of family planning & & & & \\
\hline Yes & $63(53.4)$ & $168(76.7)$ & $0.35(0.22-0.56)$ & $<0.0001$ \\
\hline No & $55(46.6)$ & $51(23.3)$ & 1 & \\
\hline Time of weaning age & & & & 0.004 \\
\hline$<4$ month & $86(72.9)$ & $124(56.6)$ & $2.10(1.26-3.34)$ & \\
\hline$>4$ month & $32(27.1)$ & $95(43.4)$ & 1 & \\
\hline
\end{tabular}

In multivariate logistic regression, the water source was significantly associated with stunting. Accordingly, family using unprotected water sources for drinking were 3.20 more likely to have stunted $\mathrm{AOR}=3.20,95 \% \mathrm{Cl}(1.74-5.73)$ child compared to families using protected water sources. Monthly income was also one of the independent predictors of stunting: those who were earning below 3000 (103\$) were 2.59 times more likely to be stunted (AOR $=2.59,95 \%(1.44-4.66)$ compared to those earned less than 3000 birrs (103\$) per month. The significantly associated factors are illustrated in the following table (Table 7) 
Table 7

Independent predictor of stunting under-five in Shire Endassilasie town, north, West, Tigray, Ethiopia in 2017

\begin{tabular}{|c|c|c|c|c|c|}
\hline \multirow[t]{2}{*}{ Characteristics } & \multicolumn{2}{|c|}{ Height for age } & \multirow[t]{2}{*}{ AOR $(95 \% \mathrm{Cl})$} & \multirow[t]{2}{*}{ P-value } & \multirow[t]{2}{*}{ S. E } \\
\hline & Stunted (\%) & Normal (\%) & & & \\
\hline \multicolumn{6}{|l|}{ Water source } \\
\hline Unprotected water source & $56(47.5)$ & $64(29.5)$ & $3.20(1.74-5.73)$ & \multirow[t]{2}{*}{$<0.0001$} & \multirow[t]{2}{*}{0.30} \\
\hline Protected water source & $62(52.5)$ & $155(70.8)$ & 1 & & \\
\hline \multicolumn{5}{|l|}{ Monthly income } & \multirow[t]{3}{*}{0.30} \\
\hline$\leq 3000$ birr & $96(81.4)$ & $140(63.9)$ & $2.59(1.44-4.66)$ & \multirow[t]{2}{*}{0.002} & \\
\hline$>3000$ birr & $22(18.6)$ & $79(36.1)$ & 1 & & \\
\hline \multicolumn{5}{|c|}{ Having enough time to prepare meals } & \multirow[t]{3}{*}{0.39} \\
\hline Yes & $86(73.5)$ & 203(93.5) & $0.26(0.12-0.56)$ & \multirow[t]{2}{*}{0.001} & \\
\hline No & $31(25.5)$ & $14(6.5)$ & 1 & & \\
\hline \multicolumn{6}{|l|}{ Time of breast feeding } \\
\hline When cry only & $86(72.9)$ & $124(56.6)$ & $2.22(1.24-3.99)$ & \multirow[t]{2}{*}{0.007} & \multirow[t]{2}{*}{0.29} \\
\hline According to time & $32(27.1)$ & $95(43.4)$ & 1 & & \\
\hline \multicolumn{6}{|l|}{ Usage of family planning } \\
\hline Yes & $63(53.4)$ & 168(76.7) & $0.59(0.31-0.90)$ & \multirow[t]{2}{*}{0.02} & \multirow[t]{2}{*}{0.27} \\
\hline No & $55(46.6)$ & $51(23.3)$ & 1 & & \\
\hline
\end{tabular}

\section{Discussion}

The intention of this study was to measure the prevalence and associated factors of stunting among preschool children of shire Endassilasie. Stunting is a cumulative process that can begin in utero and continues to about three years after birth. In the study area, the prevalence of stunting was $35 \%$. There was a slight age difference in stunting between the study group as the prevalence was $18.1 \%$ and 16.9 among male and female respectively. Significant difference among age group was also detected marking higher prevalence among 24-47 months of age group (15.1\%), followed by $48-59$ months (10.4\%) then the least among study participant were age group of less than 24 months with the prevalence of $9.5 \%$.

The $35 \%$ stunting prevalence testifies that the population in this area is affected by high risk of malnutrition according to the WHO classification of severity of malnutrition [16]. The prevalence of stunting among the study population was almost the same when compared with the study conducted in other areas with reasonably high malnutrition burden. For instance the study conducted in Bangladesh, 
Indonesia and Pakistan showed the stunting prevalence of $36.1 \%, 33.7 \%$ and $55 \%$ respectively $[18,19$, 24]. The same finding was also recorded in the study conducted at Jigjiga town Eastern Ethiopia showing $34.9 \%$ of under five were stunted [17]. However, the study conducted in northern part of Ethiopia showed the lower result when compared to the result obtained from this study. For example the detected prevalence in Libo Kemekem, Lalibela town, Wukro town and Medabay Zena were 49.4\%, 47.3\%, 49.2\% and $56.7 \%$ respectively [20-23]. The difference could be attributed to the difference in the study period, variation in the age category of target populations, Geographic location and the recently initiated nutrition-sensitive intervention activities in the study area.

The finding our study was higher when compared to the study conducted in Southern part of Ethiopia. with this, the stunting prevalence of the study finding in Kembata, Hawassa and Wolaita Sodo shows $18.8 \%, 26.6 \%$ and $27 \%$ respectively [25-27]. In Ethiopia there is the difference in socioeconomic, culture, feeding habits, environmental factors, and public service utilization of the community in the study area between Southern and Northern part. Therefore, it's believed that the difference in stunting prevalence might have been contributed by such variation in socio cultural differences between southern and northern part of the country. Additionally, the finding of this study showed that the stunting prevalence increases with the age of the child. This association is inline with other studies conducted in the North and Northwest Ethiopia [29,30]. This might be due to the nutritional status of the mother since stunting has a chronic and cyclic nature. Additionally, poor dietary practice, weaning, lower and inappropriate breast and complementary feeding practices have an effect on child growth as age increases. The other possible explanation for the increased risk of stunting might be due to environmental factors like poor sanitation and hygiene practice which increase the risk of choric malnutrition.

There is also variation in stunting prevalence between male and female. This result in line with studies conducted in Ethiopia [31], Nigeria [32] and the sub-Saharan countries [33]. This could be because of social factors like favoritism towards daughters [33]. Environmental factors such as parasitic infections like intestinal helminths could be worse the existing malnutrition. Additionally, biological factors including the common child illness predominately affect males than females and this in turns contribute for the higher prevalence among males [31].

Choric malnutrition arises from multifaceted and interrelated circumstances in which food security is the core factor. The present study showed that monthly income was significantly associated with stunting. The odd of being stunted is substantially higher among the low income group. This finding suggests that a child's health status depends upon the socio-economic status of their families. Similar association was seen in studies conducted in Holeta Town [34], Wolayta sodo [27], Lasta district [35]. This could be due to the fact that rich households have greater purchasing power of food to maintain the health of their children. However, being rich is not guaranteed according to the WHO report, stunting may also arise due to inadequate knowledge of food, feeding practices, inappropriate food allocation, and poor hygiene practices [36]. 
Additionally, this study identified that water source is one the factor associated with child stunting. Children from households using unprotected water sources are more likely to be stunted than children from households that are using protected sources. This is also supported by other similar studies conducted in Arba Mich[37], Medebay Zena [23]. Other study conducted out of Ethiopia showed similar finding; for instance study conducted in Tanzania [38], Zambia and other 59 countries [39] showed the same results. Unsafe drinking water causes diarrheal diseases thereby inhibiting nutrient absorption, which can lead to under nutrition and stunting.

Our results show that having enough time to prepare a meal is inversely associated with the child stunting. The odd of stunting among busy mothers to prepare a meal for their child is 3.8 times compared to children's from mothers that have enough time to prepare meal. Consistent finding has been observed in studies conducted in Southern [25, 40] and Eastern [41] part of Ethiopia and Bangladesh [42]. This commonly related to the mother's occupational status that impacts the intimacy with their child. Additionally, mothers who spent most of their time out of a home cannot provide sufficient care for their child. Therefore, busy mothers have short period to breastfeed their child, enforced to cease breastfeeding early that increase exposure to bottle feeding and improper complementary feeding practice.

This study also identified a significant association between stunting and time of breast feeding. Children who breast feed as per the feeding frequency have less chance of being stunted compared to children that feed in response to crying. A imilar association was seen in the studies conducted in Guto Gida of East Wollega [43], Sidama [44] and Lasta district [35]. Proper breastfeeding has an impact on averting early infant death as well as reducing child stunting. However, breast feeding practice could be affected by socioeconomic factors like low parental education especially mother's education, mothers' employment and another poor socio-economic status.

Another identified association was family planning usage and child stunting. Mothers who use family planning have lower chance of having stunted children when compared to nonusers of family planning. This finding was in line with studies conducted in the Sodo Zuria District of Ethiopia [45] and India [46]. The observed association might be due to loss of macro and micronutrient that occurs due to repeated pregnancy, delivery and breast feeding. Moreover, unplanned childbearing could elevate the risk of intrauterine growth restriction (IUGR), low birth weight (LBW), premature birth, and small birth size [47].

Even though this study shows reliable finding when compared with domestic and international journals, it exhibits the following limitations. The study cannot declare a temporal relationship between stunting and other independent variables because cross-sectional design was used for this study. Even though standard procedures were used for the measurement of height/length, measurement errors are inevitable especially within evaluators. Moreover, there might be a recall bias in reporting the age of children.

\section{Conclusion}

Our findings demonstrate a higher prevalence of stunting in Shire Endaslassie's district and this justify that malnutrition is the major public health concern in this area. This study also revealed that a monthly 
income, water source, frequency of feeding, time of breastfeeding and usage of family planning are the major predictor of stunting. Therefore, strong nutrition-specific and sensitive intervention should be implemented in the study area to avert the long effect of malnutrition.

\section{Abbreviations}

EDHS: Ethiopian Demographic Health Survey HAZ: Height for age z score, IUGR: Intra Uterine growth restriction, LBW: low birth weight, WHO: World Health Organization

\section{Declarations}

\section{Acknowledgements}

We are grateful to Shire Endaslassie town Health Office for their cooperation during the data collection. We also thank data collectors, supervisors and study participants for their immense contribution for successful accomplishment of this study.

\section{Ethics approval and consent to participate}

A letter of permission and cooperation was taken from the Department of Public Health, College of Medicine and Health Sciences of Aksum University and it was given to Shire Endaslassie town Health Office. Information on the study was given to the participants, including purpose and procedures, potential risk and benefits using oral consent, so that, they provide accurate and honest responses. Since all study participants were less than 16 years, assent was obtained from the children/adolescents and permission was obtained from respective parents/caretakers. The confidentiality of information was assured and insured. Participants were treated with respect and willingly participated in the study with no payment or coercion.

\section{Consent for publication}

Not applicable

\section{Availability of data and materials}

All data used are available within the manuscript

\section{Competing interests}

The Authors declared no competing interest 


\section{Funding}

There is no organization that financially support this research

\section{Authors' contributions}

NT and MZ wrote the proposal, participated in data collection, analyzed the data and drafted the paper.

DG approved the proposal, participated in data analysis and revised the drafts of the paper. All authors read and approved the final manuscript.

\section{References}

1. Bharati S, Chakrabarty S, Som S, Pal M, Bharati P. Socio-economic determinants of underweight children in West Bengal, India. Asian Pacific Journal of Tropical Medicine. 2010 Apr;3(4):322-7.

2. Bogale TY, Bala ET, Tadesse M, Asamoah BO. Prevalence and associated factors for stunting among 6-12 years old school age children from rural community of Humbo district, Southern Ethiopia. BMC Public Health. 2018 Dec;18(1):653.

3. Kossmann J, Nestel P, Herrera M.G, El Amin A, Fawzi W. Undernutrition in relation to childhood infections: a prospective study in the Sudan I [Internet]. [cited 2020 Feb 10]. Available from: https://www.nature.com/articles/1600998

4. Olofin I, McDonald CM, Ezzati M, Flaxman S, Black RE, Fawzi WW, et al. Associations of Suboptimal Growth with All-Cause and Cause-Specific Mortality in Children under Five Years: A Pooled Analysis of Ten Prospective Studies. Wiley AS, editor. PLoS ONE. 2013 May 29;8(5): e64636.

5. Coly AN, Milet J, Diallo A, Ndiaye T, Bénéfice E, Simondon F, et al. Preschool Stunting, Adolescent Migration, Catch-Up Growth, and Adult Height in Young Senegalese Men and Women of Rural Origin. The Journal of Nutrition. 2006 Sep 1;136(9):2412-20.

6. Whincup PH, Kaye S, Owen CG, Cook DG, Anazawa S. Birth Weight and Risk of Type 2 Diabetes: A Systematic Review. JAMA. 2008 Dec 24;300(24):2886.

7. Adair LS, Fall CHD, Osmond C, Stein AD, Martorell R, Ramirez-Zea M, et al. Associations of linear growth and relative weight gain during early life with adult health and human capital in countries of low and middle income: findings from five birth cohort studies. Lancet. 2013 Aug 10;382(9891):52534.

8. Victora CG, Adair L, Fall C, Hallal PC, Martorell R, Richter L, et al. Maternal and child undernutrition: consequences for adult health and human capital. The Lancet. 2008 Jan;371(9609):340-57.

9. Hoddinott J, Alderman H, Behrman JR, Haddad L, Horton S. The economic rationale for investing in stunting reduction: Economic rationale for stunting reduction. Matern Child Nutr. 2013 Sep; 9:69-82.

10. Grantham-McGregor S, Cheung YB, Cueto S, Glewwe P, Richter L, Strupp B. Developmental potential in the first 5 years for children in developing countries. The Lancet. 2007 Jan;369(9555):60-70. 
11. WHO. WHO | Reducing stunting in children: equity considerations for achieving the global targets 2025 [Internet]. [cited 2020 Feb 10]. Available from:

https://www.who.int/nutrition/publications/severemalnutrition/reducing-stunting-children-equity/en/

12. Central Statistical Agency (CSA) [Ethiopia], ICF. Ethiopia Demographic and Health Survey 2016 [Internet]. [cited 2020 Feb 10]. Available from: https://dhsprogram.com/publications/publicationfr328-dhs-final-reports.cfm

13. Wirth JP, Rohner F, Petry N, Onyango AW, Matji J, Bailes A, et al. Assessment of the WHO Stunting Framework using Ethiopia as a case study: Assessment of WHO Stunting Framework - Ethiopia case study. Maternal \& Child Nutrition. 2017 Apr;13(2):e12310.

14. B-Stunting-policy-brief-full-report-05-23-19 - Google Search [Internet]. [cited 2020 Feb 10]. Available from: ttps://www.ephi.gov.et/images/files/B-Stunting-policy-brief-full-report-05-23-19.pdf

15. Shire Inda Selassie - Wikipedia [Internet]. [cited 2020 Feb 10]. Available from: https://en.wikipedia.org/wiki/Shire_Inda_Selassie

16. WHO. Nutrition Landscape Information System (NLIS) country profile indicators: interpretation guide [Internet]. [cited 2020 Feb 10]. Available from: https://apps.who.int/iris/handle/10665/44397

17. Mihrete Y. Assessment of Stunting, Wasting Rate and Associated Factors among Children 0-59 Months at Jigjiga Town in Somali Regional State, Ethiopia. J Food Nutr Popul Health [Internet]. 2018 [cited 2020 Feb 10];02(01). Available from: http://www.imedpub.com/articles/assessment-ofstunting-wasting-rate-andassociated-factors-among-children-059months-at-jigjiga-town-in-somaliregionalstate-ethiopi. php?aid $=22549$

18. Vonaesch P, Tondeur L, Breurec S, Bata P, Nguyen LBL, Frank T, et al. Factors associated with stunting in healthy children aged 5 years and less living in Bangui (RCA). Wieringa F, editor. PLoS ONE. 2017 Aug 10;12(8): e0182363.

19. Titaley CR, Ariawan I, Hapsari D, Muasyaroh A, Dibley MJ. Determinants of the Stunting of Children Under Two Years Old in Indonesia: A Multilevel Analysis of the 2013 Indonesia Basic Health Survey. Nutrients. 2019 May 18;11(5):1106.

20. Geberselassie SB, Abebe SM, Melsew YA, Mutuku SM, Wassie MM. Prevalence of stunting and its associated factors among children 6-59 months of age in Libo-Kemekem district, Northwest Ethiopia; A community based cross sectional study. Gatton ML, editor. PLoS ONE. 2018 May 3;13(5): e0195361.

21. M yalew B. Prevalence and Factors Associated with Stunting, Underweight and Wasting: A Community Based Cross Sectional Study among Children Age 6-59 Months at Lalibela Town, Northern Ethiopia. J Nutr Disorders Ther [Internet]. 2014 [cited 2020 Feb 10];04(02). Available from: http://omicsonline.org/open-access/prevalence-and-factors-stunting-underweight-wastingcommunity-cross-sectional-study-children-age-months-lalibela-town-northern-ethiopia-2161-0509-4147. php?aid $=31603$

22. Gebru TT, Tesfamichael YA, Bitow MT, Assefa NE, Abady GG, Mengesha MB, et al. Stunting and associated factors among under-five children in Wukro town, Tigray region, Ethiopia: a cross 
sectional study. BMC Res Notes. 2019 Dec;12(1):504.

23. Alemayehu M, Tinsae F, Haileslassie K, Seid O, Gebregziabher G, Yebyo H. Undernutrition status and associated factors in under-5 children, in Tigray, Northern Ethiopia. Nutrition. 2015 Jul;31(7-8):96470.

24. Shah SM, Selwyn BJ, Luby S, Merchant A, Bano R. Prevalence and correlates of stunting among children in rural Pakistan. Pediatr Int. 2003 Feb;45(1):49-53.

25. Agedew E, Chane T. Prevalence of Stunting among Children Aged 6-23 Months in Kemba Woreda, Southern Ethiopia: A Community Based Cross-Sectional Study. Advances in Public Health. 2015; 2015:1-6.

26. Berhanu B, Kinfe E, Fikre K, Bosha T. Stunting and Its Associated Factors in Under Five Years Old Children: The Case of Hawassa University Technology Villages, Southern Ethiopia. 2016 Nov 1;

27. Eshete H, Abebe Y, Loha E, Gebru T, Tesheme T. Nutritional status and effect of maternal employment among children aged 6-59 months in Wolayta Sodo Town, Southern Ethiopia: a cross-sectional study. Ethiop J Health Sci. 2017 Mar 15;27(2):155.

28. Rollet SR, Gray ES, Previl H, Forrester JE. Prevalence of malnutrition in children under five and schoolage children in Milot Valley, Haiti. Public Health. 2014 Dec;128(12):1094-8.

29. Herrador Z, Sordo L, Gadisa E, Moreno J, Nieto J, Benito A, et al. Cross-Sectional Study of Malnutrition and Associated Factors among School Aged Children in Rural and Urban Settings of Fogera and Libo Kemkem Districts, Ethiopia. Jaspan HB, editor. PLoS ONE. 2014 Sep 29;9(9): e105880.

30. Mulugeta A, Hagos F, Stoecker B, Kruseman G, Linderhof V, Abraha Z, et al. Nutritional Status of Adolescent Girls from Rural Communities of Tigray, Northern Ethiopia. Ethiopian Journal of Health Development [Internet]. 2009 Aug 3 [cited 2020 Feb 10];23(1). Available from: http://www.ajol.info/index.php/ejhd/article/view/44831

31. Tariku EZ, Abebe GA, Melketsedik ZA, Gutema BT. Prevalence and factors associated with stunting and thinness among school-age children in Arba Minch Health and Demographic Surveillance Site, Southern Ethiopia. Laar A, editor. PLoS ONE. 2018 Nov 2;13(11):e0206659.

32. Oninla SO, Owa JA, Onayade AA, Taiwo O. Comparative Study of Nutritional Status of Urban and Rural Nigerian School Children. Journal of Tropical Pediatrics. 2006 Sep 29;53(1):39-43.

33. Wamani H, Åstrøm AN, Peterson S, Tumwine JK, Tylleskär T. Boys are more stunted than girls in SubSaharan Africa: a meta-analysis of 16 demographic and health surveys. BMC Pediatr. 2007 Dec;7(1):17.

34. Tesfamariam K, Yilma D. Prevalence of Stunting and its Associated Factors Among Children Under 5 Age in Holeta Town , West Shoa Zone, Oromia Region , Ethiopia , 2017. In EC NUTRITION; 2017.

35. Abebaw D. Stunting and Associated Factors among Children Aged 6-59 Months in Lasta Woreda, North East Ethiopia, 2015: A Community Based Cross Sectional Study Design. Journal of Family Medicine. 2017 Mar 10;4. 
36. Alderman HH, Elder LK, Goyal A, Herforth AW, Hoberg YT, Marini A, et al. Improving nutrition through multisectoral approaches [Internet]. The World Bank; 2013 Jan [cited 2020 Feb 10] p. 1-178. Report No.: 75102. Available from: http://documents.worldbank.org/curated/en/625661468329649726/Improving-nutrition-throughmultisectoral-approaches

37. Gebremeskel F. Determinants of Acute Malnutrition among Under-Five Children in Karat Town Public Health Facilities, Southern Ethiopia: A Case Control Study. 2017 Aug 15;

38. Chirande L, Charwe D, Mbwana H, Victor R, Kimboka S, Issaka Al, et al. Determinants of stunting and severe stunting among under-fives in Tanzania: evidence from the 2010 cross-sectional household survey. BMC Pediatr. 2015 Dec;15(1):165.

39. Headey D, Palloni G. Water, Sanitation, and Child Health: Evidence from Subnational Panel Data in 59 Countries. Demography. 2019 Apr;56(2):729-52.

40. Fikadu T, Assegid S, Dube L. Factors associated with stunting among children of age 24 to 59 months in Meskan district, Gurage Zone, South Ethiopia: a case-control study. BMC Public Health. 2014 Dec;14(1):800.

41. Mesfin F, Worku A, Birhane Y. Prevalence and associated factors of stunting among primary school children in Eastern Ethiopia. NDS. 2015 Sep;61.

42. Das S, Gulshan J. Different forms of malnutrition among under five children in Bangladesh: a cross sectional study on prevalence and determinants. BMC Nutr. 2017 Dec;3(1):1.

43. Adeba A, Garoma S, Fekadu Gemede H, Garoma W. Prevalence of Stunting and Associated Factors of Children among 6-59 Months Age in Guto Gida District, East Wollega Zone, Oromia, Ethiopia. Food Science and Quality Management. 2014 Jul 4;2014.

44. Tessema M, Belachew T, Lombamo GE. Feeding patterns and stunting during early childhood in rural communities of Sidama, South Ethiopia. The Pan African medical journal. 2013 Feb 26; 14:75.

45. Dake SK, Solomon FB, Bobe TM, Tekle HA, Tufa EG. Predictors of stunting among children 6-59 months of age in Sodo Zuria District, South Ethiopia: a community based cross-sectional study. BMC Nutr. 2019 Dec;5(1):23.

46. Abhishek K, V. K. S. Study of Exclusive Breastfeeding and its impact on Nutritional Status of Child in EAG States - Google Search [Internet]. [cited 2020 Feb 11]. Available from: http://dx.doi.org/10.12785/jsap/040311

47. Rana MJ, Gautam A, Goli S, Uttamacharya, Reja T, Nanda P, et al. Planning of births and maternal, child health, and nutritional outcomes: recent evidence from India. Public Health. 2019 Apr; 169:1425. 